\title{
Treatment of petroleum refinery wastewater by electrochemical oxidation using graphite anodes
}

\author{
Sajjad S. Jawad ${ }^{a}$ and Ali H. Abbar ${ }^{a *}$ \\ ${ }^{a}$ Department of chemical engineering, University of Al-Qadisiyah, Al-Qadisiyah, Iraq.
}

\author{
ARTICLE INFO \\ Article history: \\ Received 05 August 2019 \\ Received in revised form 23 September 2019 \\ Accepted 28 September 2019
}

Keywords:

Electrochemical oxidation

COD removal

Graphite anode

Petroleum refinery wastewater

Phenol

\begin{abstract}
A B S TRACT
An electrochemical oxidation method was performed in a batch electrochemical reactor using graphite anodes for treating an effluent obtained from Al-Diwaniyah petroleum refinery plant. The effective f process parameters like current density (4-20 $\left.\mathrm{m} \mathrm{Acm}^{-2}\right), \mathrm{pH}(3-9)$, and $\mathrm{NaCl}$ concentration (0-3 g/l) on the COD and phenol removal efficiency have been investigated. The results reveal that the best conditions were current density $12 \mathrm{~mA} \mathrm{~cm}{ }^{-2}, \mathrm{pH} 7, \mathrm{NaCl}$ concentration $2 \mathrm{gl}^{-1}$ at a treatment time of 60 minutes. Under best conditions of COD removal efficiency $100 \%$ and phenol removal efficiency $99.12 \%$ were obtained at current efficiency $33.5 \%$ and power consumption $59.9 \mathrm{kWh} / \mathrm{kg}$ COD. The anodic oxidation was proven to be efficient for treatment Al-Diwaniyah petroleum refinery effluent to get effluent with features in agreement with the standard limits for discharge to the environment at a lower cost.
\end{abstract}

(C) 2019 University of Al-Qadisiyah. All rights reserved.

\section{Introduction}

The petroleum refinery industry converts crude oil into its major fractions that can be additionally handled through a series of physical, thermal, and chemical conversion and separation steps into valuable petroleum products such as gasoline, kerosene, Liquefied Petroleum Gas (LPG), fuel oil, diesel fuels, waxes, and lubrication oils [1]. For the purpose of manufacturing the above mentioned products, huge quantities of water are used in refinery processes, especially for distillation, hydro-treating, thermal cracking and catalytic cracking, desalting and cooling systems. Petroleum refining process generates wastewater of about 1.6 times the volume of the processed crude oil. The characteristics of petroleum refinery effluents are usually influenced by the production mode, plant configuration and types of oil [2]. Generally, the petroleum refinery effluents contain high concentrations of inorganic and organic compounds, chemical additives (surfactants and inhibitors of corrosion), suspended solids, chloride, oil, and grease which added to effluent during the operations of producing petroleum products [3]. This petroleum refinery effluent is usually rich in Biological Oxygen Demand (BOD) and Chemical Oxygen Demand (COD) which are responsible for damaging plants, sea, river as well as to surface and groundwater sources [4]. The polluted wastewater generated by refineries contains COD levels of approximately $300-600 \mathrm{mg} / \mathrm{L}$ but not limited ; benzene levels of $1-100 \mathrm{mg} / \mathrm{L}$; phenol levels of $20-200 \mathrm{mg} / \mathrm{L}$, heavy metals levels of $(0.2-10 \mathrm{mg} / \mathrm{L} \mathrm{Pb}$ and $0.1-100 \mathrm{mg} / \mathrm{L} \mathrm{Cr})$; and other pollutants. . However, concentration of phenol can alter based on the nature of the process [5]. The concentration of Phenol in the range 5-25 $\mathrm{mg} \mathrm{L}^{-1}$ considers as a toxic material for humans and aquatic life, therefore the highest allowable limits of phenol in petroleum refinery effluents should be in the range of $0.5-1.0 \mathrm{mg} \mathrm{L}^{-1}$ [6] . A maximum acceptable limit of $<0.0005 \mathrm{mg} \mathrm{L}^{-1}$ for phenol in potable drinking water was assigned by the European Union (EU), in its 80/778/EC directive [7]. Direct discharging of these effluents could result in many environmental pollution issues. Approximately 80-90 percent of the water used in the petroleum refinery plants is discharged as wastewater, therefore applying of wastewater treatment is not only to avoid environmental pollution issues but also to reuse of the water again hence another economic benefit for oil refineries [8]. Methods used for the treatment of petroleum refinery effluent involve coagulation [9], chemical oxidation [10], advanced oxidation processes

* Corresponding author.

E-mail address: aliabbar68@yahoo.com (Ali H Abbar) 


\begin{tabular}{|ll}
\hline Nomenclature \\
$C O D$ & Chemical oxidation demand $\left(\left(\mathrm{mg} \mathrm{L}^{-1}\right)\right.$ \\
$T D S$ & Total dissolved solid $\left(\left(\mathrm{mg} \mathrm{L}^{-1}\right)\right.$ \\
$B O D$ & Biological oxygen demand $\left(\mathrm{mg} \mathrm{L}^{-1}\right)$ \\
DSA & Dimensionally stable anode \\
Cond & Conductivity $(\mu \mathrm{S} / \mathrm{cm})$ \\
$C_{i}$ & Initial concentration $\left(\mathrm{mg} \mathrm{L}^{-1}\right)$ \\
$C_{f}$ & Final concentration $\left(\mathrm{mg} \mathrm{L}^{-1}\right)$ \\
$R E$ & Removal efficiency $(\%)$ \\
$C E$ & Current efficiency $(\%)$
\end{tabular}

[11], adsorption [12], biological approaches [13], membrane treatment [14], and electrochemical techniques $[15,16]$. Generally, in most these methods, the approach is to transform of pollutants from one medium to another at low efficiency, besides, the choice of any method for treating the effluents of petroleum refinery depends on the composition of these effluents and the final purpose of effluents (discharge or reuse). Among them, electrochemical treatment methods have attracted attention due to the numerous advantages gained by these methods such as versatility, selectivity, and cost effectiveness [17]. Besides, electrochemical reactions are not depended on the properties of the wastewater and can use any value of current to be supplied to the electrochemical reactor [18]. One of the most important electrochemical methods is the anodic oxidation (also known as electrochemical incineration) which depends on generation of hydroxyl (strong oxidant) on the surface of an electroactive anode then these radicals attack the organic compounds existing in wastewaters and transform them to water and $\mathrm{CO} 2$ [19]. In contrast to chemical and advanced oxidation processes, like Fenton reaction which based on using iron ions and hydrogen peroxide as reagents in its chemical mechanism, as well as photo-Fenton process which used Fenton reagents with Ultra violet (UV) radiation to generate the hydroxyl radical, anodic oxidations do not need to use or stored of dangerous substances, in addition to easiness of scale-up. Other benefits involve low labour requirements since the processes are fairly simple and could be automatized. The method gives environmental advantages, as it uses electron as the main reagent [20]. During an anodic oxidation process, organic compounds can be incinerated by direct or indirect oxidation. In a direct process, the pollutants are first adsorbed on the surface of an anode and then undergo an oxidation reaction via transfer of electrons directly. In this case, the material of the electrode used for oxidation of organic compounds is the most important variables to be taken into account for obtaining high rates of electro-oxidation. The oxidation powers of many types of anodes like Boron-Doped Diamond (BDD), Dimensionally Stable Anode (DSA), lead dioxide ( $\mathrm{PbO} 2$ ), and doped-SnO2 have been investigated for the direct oxidation of many organic substances such as phenol [21-24]. Among these electrodes, BDD is the best anodic material for degradation of organic compounds, because it has a wide potential window for discharging of water and its ability to generate weakly adsorbed hydroxyl radicals which giving rapid and efficient anodic oxidation [19]. Besides, BDD electrode has higher stability and chemical-resistant than other anodes which enables it to be used for a long time justifying its high cost. At the indirect processes, strong oxidants such as hypochlorite/chlorine, hydrogen peroxide, and ozone are generated by anodic oxidation then reacted with the organic compounds in the bulk solution [25, 26]. Chloride is particularly engaging for use in the indirect oxidation due to the presence of chloride salts in wastewaters [27]. Furthermore, previous works confirmed the role of active chlorine in the anodic oxidation of dyes and different organic substances [28]. Adding of chloride ions to the effluents was found by many researchers to be contributed in minimizing the energy consumption because of the enhancing in the current efficiency and oxidation kinetics as well as

$\begin{array}{ll}F & \text { Faraday's constant }(96487 \mathrm{C} / \mathrm{mol}) \\ V & \text { Effluent volume }(\mathrm{L}) \\ \Delta \mathrm{C} & \text { COD Difference values }(\mathrm{g} / \mathrm{L}) \\ I & \text { Current }(\mathrm{A}) \\ t & \text { Electrolysis time }(\mathrm{s}) \\ E C & \text { Electrical energy consumption }(\mathrm{kWh} / \mathrm{kg}) \\ \mathrm{U} & \text { Applied cell voltage (Volt) } \\ \mathrm{COD}_{\mathrm{i}} & \text { Initial chemical oxygen demand }\left(\mathrm{mg} \mathrm{L}^{-1}\right) \\ \mathrm{COD}_{\mathrm{f}} & \text { Final chemical oxygen demand }\left(\mathrm{mg} \mathrm{L}^{-1}\right)\end{array}$

reducing of cell potential $[29,30]$.

In the present work, indirect anodic oxidation process was used to remove Chemical Oxygen Demand (COD) and phenol from petroleum refinery wastewater resulted from Al-Diwaniyah petroleum refinery plant using a batch electrochemical reactor in which the effect of different parameters such as current density, $\mathrm{pH}$, and $\mathrm{NaCl}$ concentration were investigated.

\section{2- Experimental work}

Petroleum refinery effluent samples were provided by Al-Diwaniyah petroleum refinery plant. Sample (20L) was collected from the feed tank to the biological treatment unit and stored in closed containers at temperature $4{ }^{\circ} \mathrm{C}$ until use. Characterization of this sample is shown in table 1 . Besides the properties of effluent taken from the settling tank of the final stage of the biological treatment that was measured by petroleum refinery plant administration with the permissible limit were mentioned in this table for comparison

Table 1. Characteristics of the effluents in Al-Diwaniyah petroleum refinery plant.

\begin{tabular}{llll}
\hline Test & $\begin{array}{c}\text { feed tank } \\
\text { sample }\end{array}$ & settling tank* & Permissible limit* $^{*}$ \\
\hline $\mathrm{COD}(\mathrm{mg} / \mathrm{l})$ & 160 & 65 & 100 \\
$\mathrm{pH}$ & 7.8 & 7.5 & $(6-9.5)$ \\
$\mathrm{T} . \mathrm{D} . \mathrm{S}$ & 1710 & 1680 & ---- \\
$\mathrm{Cl}(\mathrm{mg} / \mathrm{l})$ & 931 & 119 & 100 \\
$\mathrm{SO}_{4}(\mathrm{~m} / \mathrm{l})$ & 560 & 400 & 400 \\
Turb. & 5.17 & 6.44 & 41.3 \\
Cond. $(\mu \mathrm{S} / \mathrm{cm})$ & 3320 & --- & ---- \\
Phenol $(\mathrm{mg} / \mathrm{l})$ & 0.17 & $(0.01-0.05)$ & 0.06 \\
\hline *provided by Al-Diwaniyah petroleum refinery plant administration
\end{tabular}

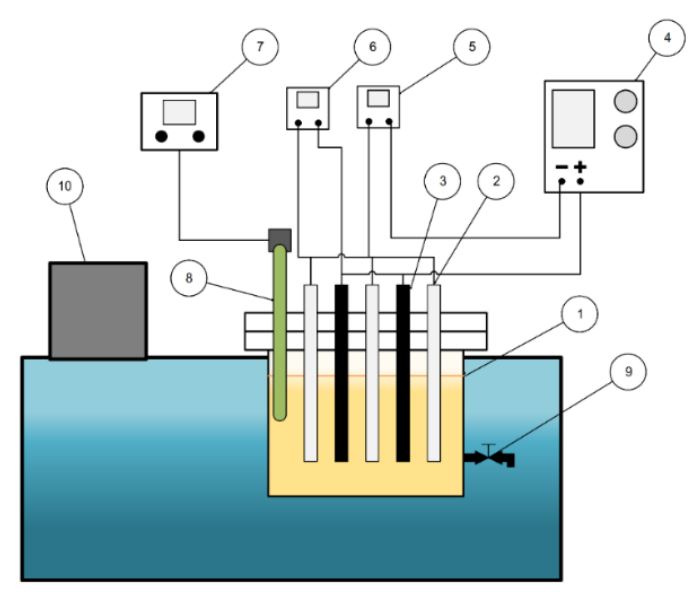

Figure 1. The electrochemical system: 1) cell body, 2) cathode (stainless steel), 3) Anode(graphite), 4)power supply, 5)Ammeter, 6)Voltmeter, 7)pH-meter, 8) pH-probe, 9) discharge valve, 10)water bath. 
A rectangular perspex glass lab-scale batch electrochemical reactor was used for the anodic oxidation treatment experiments. It has inside dimensions (120 mm width x $120 \mathrm{~mm}$ length $\mathrm{x} 120 \mathrm{~mm}$ height) and active electrolyte volume of $1.25 \mathrm{~L}$, provided with perspex cover of external dimensions $(150 \mathrm{~mm} \times 150 \mathrm{~mm} \times 28 \mathrm{~mm}$ thickness $)$. The cover contains slits for electrodes fixation and holes for inserting the probe of $\mathrm{pH}$-meter and conductivity meter. A parallel plate configuration was adopted for the electrochemical reactor were three stainless steel plate cathodes $(130 \mathrm{~mm} \times$ $80 \mathrm{~mm} \times 3 \mathrm{~mm}$ (thickness) $)$ and two graphite anodes $(130 \mathrm{~mm} \times 80 \mathrm{~mm} \times$ $3 \mathrm{~mm}$ (thickness)) were used. The distance between cathode and anode was fixed at $15 \mathrm{~mm}$. A digital direct current power supply (0-30 V, 0-5 A) Type (UNI-T, UTP3315PF) was used to provide constant current during each experiment. In each run, $1.25 \mathrm{~L}$ solution was agitated using magnetic stirrer to achieve the proper mixing conditions then transfer to inside the cell. All the experiments were carried out at constant temperature $30^{\circ} \mathrm{C}$ using water bath (Memmert, type: WNB22, Germany). Fig.1 shows the schematic diagram of the electrochemical oxidation experimental setup supported by the required information. The electrolyte $\mathrm{pH}$ was measured using a digital pH meter (HNNA Instrument Inc.PH211, Romania) and the electrolyte acidity was adjusted by using $\mathrm{HCl}$ or $\mathrm{NaOH}$ for the appropriate experimental condition. Conductivity and TDS were measured by using (HM digital Inc. model COM-100, Korea). The samples were taken and analyzed to determine the $\mathrm{COD}$ and phenol concentration every 10 minutes of the electrolysis time.

The concentration of total organic compounds in the effluent is expressed in terms of Chemical Oxygen Demand (COD). Amount of COD in petroleum refinery effluents was measured by taken a sample $(2 \mathrm{ml})$ of effluent digested with an oxidizing agent $\left(\mathrm{K}_{2} \mathrm{Cr}_{2} \mathrm{O}_{7}\right)$ for 120 minutes at 150 ${ }^{\circ} \mathrm{C}$ in a COD thermos-reactor (RD125, Lovibond). The digested sample was cooled down to room temperature then analyzed in a spectrophotometer (MD200, Lovibond). Phenol was measured by using Method 8047 assigned by Hach Company/Hach Lange GmbH, USA [31]. Measuring of phenol concentration and COD were achieved three times and the average values were taken in this work.

The removal efficiency of COD and phenol were evaluated based on eq. (1), where $C_{i}$ is the initial concentration $\left(\mathrm{mg} \mathrm{L}^{-1}\right)$ and $C_{f}$ is the final concentration $\left(\mathrm{mg} \mathrm{L}^{-1}\right)$ [32]:

$R E \%=\frac{C_{i}-C_{f}}{C_{i}} \times 100$

The current efficiency refers to the portion of the total current used for the specified reaction. It was calculated with the theoretical value that 1 molar electrons ( 96485 coulombs charge) would be transferred via oxidizing $8 \mathrm{~g}$ COD. Assuming all the COD removal was due to the electrochemical oxidation, then by counting the charges transferred and monitoring the COD removal in the solution, the Current Efficiency(CE\%) could be estimated from equation [33]:

$C E \%=\frac{F \cdot V \cdot \Delta C}{8 I . t} \times 100$

where $\mathrm{F}$ is Faraday's constant $(96487 \mathrm{C} / \mathrm{mol})$, V is the effluent volume in (L), $\Delta \mathrm{C}$ is the difference in the COD values in $(\mathrm{g} / \mathrm{L}), \mathrm{I}$ is the current in (A), 8 is a dimensional factor for unit consistency, it is the oxygen equivalent mass $\left\{32 \mathrm{~g}\right.$ of $\mathrm{O}_{2} / 4 \mathrm{~mol}$ of electrons $\}(\mathrm{g} / \mathrm{mol})$, and $\mathrm{t}$ is the electrolysis time (s). The electrical energy consumption (EC) is the amount of energy consumed in the oxidation process for a $\mathrm{kg}$ of COD removed. EC in $(\mathrm{kWh} / \mathrm{kg})$ can be calculated by Eq. (3) [34]:

$E C=\frac{U . I . t \times 1000}{\left(\operatorname{COD}_{i}-C_{0}\right) V}$
Where $\mathrm{EC}$ is the energy consumption ( $\mathrm{kWh} / \mathrm{kg} \mathrm{COD}$ ), $\mathrm{U}$ is the applied cell voltage (Volt),I is the current (A),t is the electrolysis time (h), $\mathrm{COD}_{\mathrm{i}}$ and $\mathrm{COD}_{\mathrm{f}}$ are the initial and final chemical oxygen demand ( $\left.\mathrm{mg} / \mathrm{l}\right)$, and $\mathrm{V}$ is the effluent volume (L).

\section{Results and discussion}

\subsection{Effect of current density}

Figure 2 shows the abatement of COD with time at different current densities using effluent containing $\mathrm{NaCl}$ with a concentration of $2 \mathrm{~g} / \mathrm{l}$ and adjusted acidity initially at $\mathrm{pH}$ 7. It was clear that increasing current density leads to decrease the final COD value of the effluent. It was observed that the efficiency of degradation is higher at the initial stage of anodic oxidation; however, it then proceeded gradually as anodic oxidation continues. This behavior can be interpreted as the concentration of organic pollutants is high at the initial period of electrolysis so the electrochemical reaction is under current-limited control where nearly most the applied current is used to oxidize the organic compounds by the generated $\mathrm{OCl}^{-}$. However, the concentration of organic pollutants is reduced gradually during the electrolysis leading to make the oxidation process under mass transport control, hence a slight increase in degradation efficiency is occurred due to the taken place of side reactions, such as oxygen evolution [35] .Table 2 shows the removal efficiency of COD at different current densities where complete removal of COD was obtained at current density equal or higher than $12 \mathrm{mAcm}^{-2}$ at electrolysis time of $60 \mathrm{~min}$. The effect of current density on phenol removal efficiency is also reported in Table 2 where increasing current density results in increasing the removal efficiency of phenol. It is interesting to note that final phenol concentration is 0.0015 at current density of $12 \mathrm{mAcm}^{-2}$ which is lower than the permitted level and became lowest at higher current densities. An increase in current density would increase electricity consumption. Using current density higher than $12 \mathrm{mAcm}^{-2}$ resulted in increasing power consumption higher than $(60 \mathrm{Kwh} / \mathrm{Kg} \mathrm{COD})$, therefore it is the best to choose this current density for further investigation. Similar observations were found in previous studies [19, 34, 36, 37].

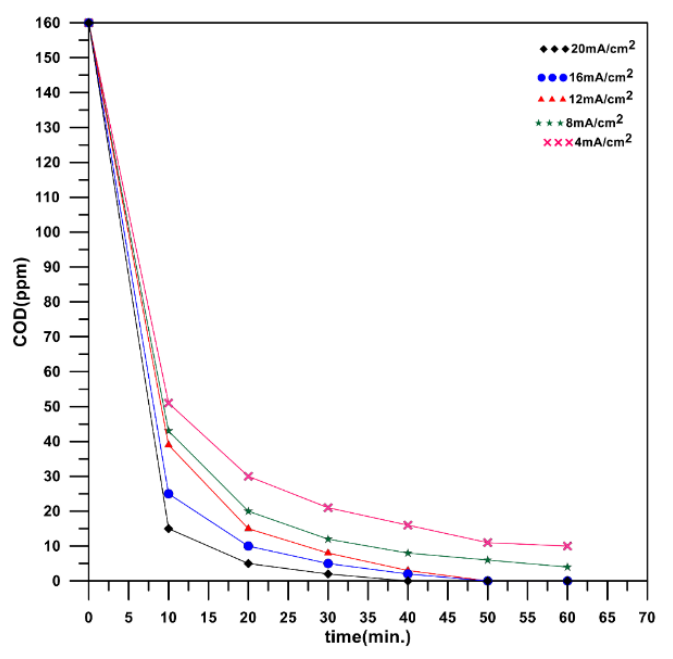

Figure 2. COD abatement with time at different current density. $\mathrm{pH}=7,[\mathrm{NaCl}]=2 \mathrm{~g} / \mathrm{l}, \mathrm{Temp} .=30 \circ \mathrm{C}$.

Figure 3 illustrates how the $\mathrm{pH}$ is affected by current density through the operation where $\mathrm{pH}$ decreased for the first $30 \mathrm{~min}$ then started to increase for further electrolysis time. Similar trend was observed by Souza and 
Ruotolo [19] in the electrochemical treatment of an oil refinery effluent using boron-doped diamond anodes, where the $\mathrm{pH}$ started to decrease initially from a $\mathrm{pH}$ value of 9.5 then increased after ( 2 hrs.) of electrolysis time suggesting the responsibility of the intermediate compounds that generated during the electrolysis for the change in $\mathrm{pH}$.

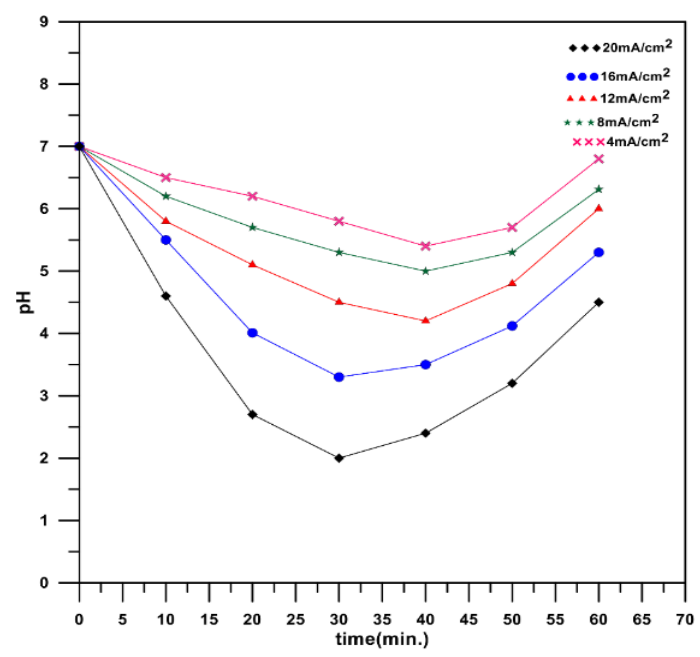

Figure $3 \mathrm{pH}$ profile with time at different current density

\subsection{Effect of $\mathrm{NaCl}$ concentration}

Figure 4 displays the abatement of $\mathrm{COD}$ with time at different $\mathrm{NaCl}$ concentration using effluent with acidity adjusted initially to $\mathrm{pH}$ 7. It was clear that increasing $\mathrm{NaCl}$ concentration leads to a decrease in the final COD value of the effluent. Table 3 reveals this behavior where the effect of $\mathrm{NaCl}$ concentration on the removal efficiency of $\mathrm{COD}$ and phenol are reported. It can be seen that increasing of sodium chloride concentration from 0 to $3 \mathrm{~g} / \mathrm{L}$ results in increasing of COD removal efficiency from 91.88 to $96.88 \%$ at abatement time of $30 \mathrm{~min}$, while a complete COD removal was obtained with and without addition of $\mathrm{NaCl}$ at various concentrations at abatement time of $60 \mathrm{~min}$. This is interesting results which confirm that chlorine ions which originally existing in the solution have the ability to degrade the pollutants even at low concentration. However, the final concertation of phenol is higher than 0.0015 at $\mathrm{NaCl}$ concentration lower than $2 \mathrm{gl}^{-1}$. It is preferred to conduct further experiments at $\mathrm{NaCl}$ concentration of $2 \mathrm{~g} / \mathrm{L}$ in which a complete removal of COD at the required level of phenol concentration discharge was achieved. Besides a negligible decrease in the energy consumption was observed at $\mathrm{NaCl}$ concentration higher than $2 \mathrm{gl}^{-1}$ also using higher concentration of $\mathrm{NaCl}$ may favor producing chlorinated organic compounds not destroyed by the anodic oxidation as proved by previous studies [38]. Similar trends were observed by Britto-Costa and Ruotolo [38] in the electrooxidation of phenol using BDD or DSA electrodes where COD removal increases with addition of $\mathrm{NaCl}$. Souza and Ruotolo [19] studied the electrochemical oxidation of oil refinery effluent using boron-doped diamond anodes. They found that addition of $450 \mathrm{mg} / \mathrm{l}$ of $\mathrm{NaCl}$ gives higher removal of COD in comparison with no addition of $\mathrm{NaCl}$. Ibrahim et al [34] investigated the electrochemical oxidation treatment of petroleum refinery effluent and found that increasing $\mathrm{NaCl}$ concentration gives higher abatement of $\mathrm{COD}$ using titanium anode. Figure 5 shows how the $\mathrm{pH}$ affected by $\mathrm{NaCl}$ concentration through the operation where $\mathrm{pH}$ is decreased for the first 30 min then started to increase for further electrolysis time. Santos et al. [37] found a similar trend in the treatment of an effluent from petroleum industry using $\mathrm{Ti} / \mathrm{RuO}_{2}$ anode where the $\mathrm{pH}$ decreases for time period shorter than 30min then start to increase after (30 min.) interpreting their results by the formation of low molecular weight of acid compounds like oxalic acid during the first period (30min.) then hypochlorite become the predominating species after that period.

Table 2. Effect of current density on COD and phenol removal efficiency

\begin{tabular}{|c|c|c|c|c|c|c|c|}
\hline \multirow{2}{*}{$\begin{array}{l}\text { Current density } \\
\mathrm{mA} / \mathrm{cm}^{2}\end{array}$} & \multicolumn{2}{|c|}{ Phenol conc. (mg/l) } & \multirow{2}{*}{$\begin{array}{l}\text { Phenol RE\% } \\
\text { at } 60 \mathrm{~min}\end{array}$} & \multicolumn{2}{|c|}{ COD Removal (\%) } & \multirow{2}{*}{$\begin{array}{l}\mathrm{CE} \\
(\%)\end{array}$} & \multirow{2}{*}{$\begin{array}{l}\text { EC } \\
(\mathrm{kWh} / \mathrm{kg})\end{array}$} \\
\hline & $\mathbf{C}_{\mathrm{i}}$ & $\mathbf{C}_{\mathrm{f}}$ & & at $30 \mathrm{~min}$ & at $60 \mathrm{~min}$ & & \\
\hline 4 & 0.17 & 0.003 & 98.23 & 86.88 & 93.75 & 78.52 & 16.89 \\
\hline 8 & 0.17 & 0.0016 & 99.05 & 92.50 & 97.50 & 40.20 & 41.15 \\
\hline 12 & 0.17 & 0.0015 & 99.12 & 95.00 & 100 & 33.50 & 59.90 \\
\hline 16 & 0.17 & 0.0005 & 99.70 & 96.88 & 100 & 25.13 & 87.14 \\
\hline 20 & 0.17 & 0.0005 & 99.70 & 98.75 & 100 & 25.13 & 103.48 \\
\hline
\end{tabular}

Table 3. Effect of $\mathrm{NaCl}$ concentration on $\mathrm{COD}$ and phenol removal efficiency

\begin{tabular}{|c|c|c|c|c|c|c|c|c|}
\hline \multirow{2}{*}{$\begin{array}{l}\text { NaCl Conc. } \\
(\mathrm{g} / \mathrm{l})\end{array}$} & \multirow[t]{2}{*}{ Initial Cond. $\mu \mathrm{s} / \mathrm{cm}$} & \multicolumn{2}{|c|}{ Phenol conc.(mg/l) } & \multirow{2}{*}{$\begin{array}{l}\text { Phenol RE\% } \\
\text { at } 60 \mathrm{~min}\end{array}$} & \multicolumn{2}{|c|}{ COD Removal (\%) } & \multirow{2}{*}{$\begin{array}{l}\mathbf{C E} \\
(\%)\end{array}$} & \multirow{2}{*}{$\begin{array}{l}\text { EC } \\
(\mathrm{kWh} / \mathrm{kg})\end{array}$} \\
\hline & & $\mathbf{C}_{\mathrm{i}}$ & $\mathrm{C}_{\mathrm{f}}$ & & at $30 \mathrm{~min}$ & at $60 \mathrm{~min}$ & & \\
\hline 0 & 3320 & 0.17 & 0.002 & 98.82 & 91.88 & 100 & 26.8 & 93.33 \\
\hline 1 & 4900 & 0.17 & 0.002 & 98.82 & 93.75 & 100 & 33.5 & 62.48 \\
\hline 2 & 6510 & 0.17 & 0.0015 & 99.12 & 95.00 & 100 & 33.5 & 59.9 \\
\hline 3 & 7900 & 0.17 & 0.0003 & 99.82 & 96.88 & 100 & 33.5 & 57 \\
\hline
\end{tabular}




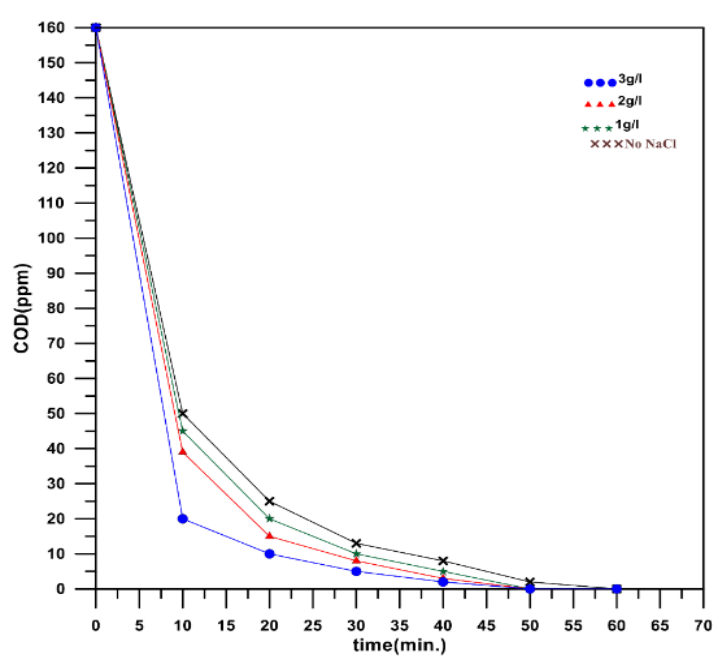

Figure 4. COD abatement with time at different $\mathrm{NaCl}$ concentrations. $\mathrm{I}=12 \mathrm{mAcm}^{-2}, \mathrm{pH}=7$, Temp. $=30 \circ \mathrm{C}$.

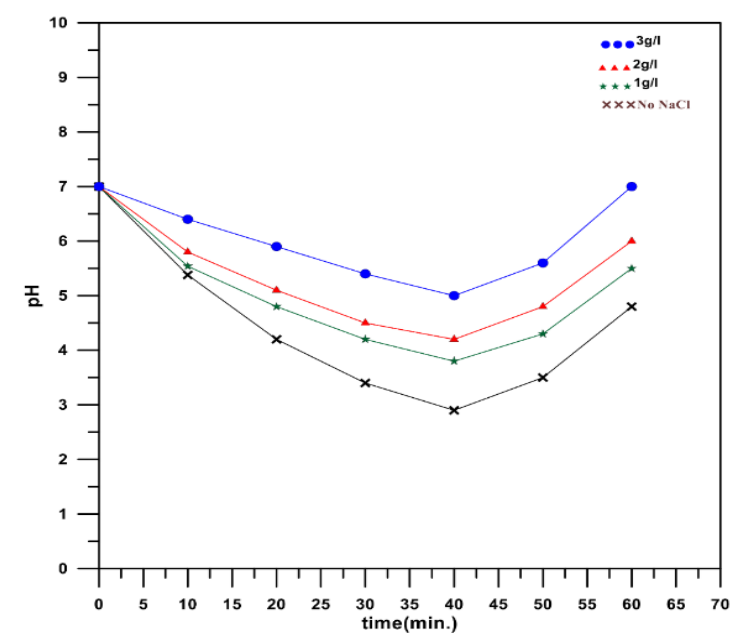

Figure $5 \mathrm{pH}$ profile with time at different $\mathrm{NaCl}$ concentrations

\subsection{Effect of $\mathrm{pH}$}

Figure 6 displays the abatement of COD with time at different $\mathrm{pH}$ using effluent containing $\mathrm{NaCl}$ at concentration of $2 \mathrm{~g} / \mathrm{l}$. It was clear that decreasing $\mathrm{pH}$ leads to decrease the final COD value of the effluent. The effect of $\mathrm{pH}$ on the removal efficiency of COD and phenol was studied and shown in Table 4. It was observed that the initial $\mathrm{pH}$ has a substantial impact on the COD and phenol removal efficiency. The maximum removal efficiency of COD and phenol was occurred at $\mathrm{pH}$ equal or lower than 7. Similar observations were made by Fil et al [39] who studied the treatment of oistachio processing industry wastewater by anodic oxidation using graphite anode in the presence of $\mathrm{NaCl}$ where higher $\mathrm{COD}$ removal was observed at acidic solutions. Ibrahim et al [34] in their study found that neutral conditions give better results than alkaline medium with respect to COD removal. This behavior can be interpreted as the anodic oxidation generally gives better results in acidic or neutral conditions than the basic conditions when chlorine ions existing in the electrolytic process where formation hypochlorous which is a more powerful oxidant than hypochlorite has happened. Previous studies approved that at alkaline conditions the active chlorine exists in the form of hypochlorite which is a less strong oxidant towards organic species in regarding to hypochlorous acid that is the main species present at $\mathrm{pH}$ approached to $3[39,40]$. On the other hand, the final concentration of phenol is higher than 0.0015 as $\mathrm{pH}$ increased and became more alkaline.

The $\mathrm{pH}$ profile with time at different initial $\mathrm{pH}$ is illustrated in Figure 7 where the $\mathrm{pH}$ is decreased for the first $30 \mathrm{~min}$ then started to increase for further electrolysis time. Similar observations were found by previous works [19, 37]. Using an initial $\mathrm{pH}$ of 7 is recommended for the environment conditions since starting with $\mathrm{pH}=3$ results in discharging effluent with $\mathrm{pH}$ lower than 6 as shown in Figure 7.

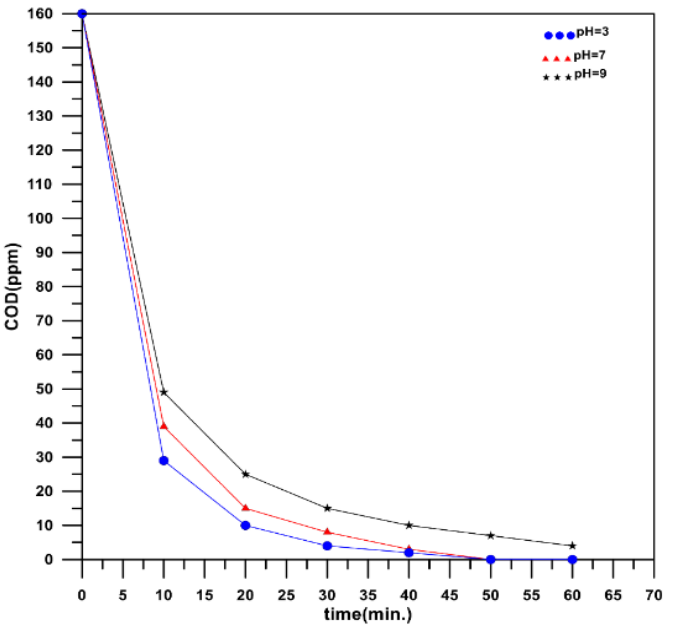

Figure 6. COD abatement with time at different $\mathrm{pH} . \mathrm{I}=12 \mathrm{mAcm}{ }^{-2}$, $[\mathrm{NaCl}]=2 \mathrm{~g} / \mathrm{l}$, Temp. $=30 \circ \mathrm{C}$.

Table 4. Effect of pH on COD and phenol removal efficiency

\begin{tabular}{|c|c|c|c|c|c|c|c|}
\hline \multirow{2}{*}{ pH } & \multicolumn{2}{|c|}{$\begin{array}{l}\text { Phenol conc. } \\
\text { (mg/l) }\end{array}$} & \multirow{2}{*}{$\begin{array}{l}\text { Phenol } \\
\text { RE\% } \\
\text { at } 60 \\
\text { min }\end{array}$} & \multicolumn{2}{|c|}{$\begin{array}{l}\text { COD Removal } \\
(\%)\end{array}$} & \multirow{2}{*}{$\begin{array}{l}\text { CE } \\
(\%)\end{array}$} & \multirow{2}{*}{$\begin{array}{l}\text { EC } \\
(\mathrm{kWh} / \mathrm{kg})\end{array}$} \\
\hline & $C_{i}$ & $C_{f}$ & & $\begin{array}{l}\text { at } 30 \\
\text { min }\end{array}$ & $\begin{array}{l}\text { At } 60 \\
\text { min }\end{array}$ & & \\
\hline 9 & 0.17 & 0.0025 & 98.53 & 90.63 & 97.5 & 27.22 & 72.03 \\
\hline 7 & 0.17 & 0.0015 & 99.12 & 95 & 100 & 33.5 & 59.9 \\
\hline 3 & 0.17 & 0.0013 & 99.23 & 97.5 & 100 & 33.5 & 56.61 \\
\hline
\end{tabular}

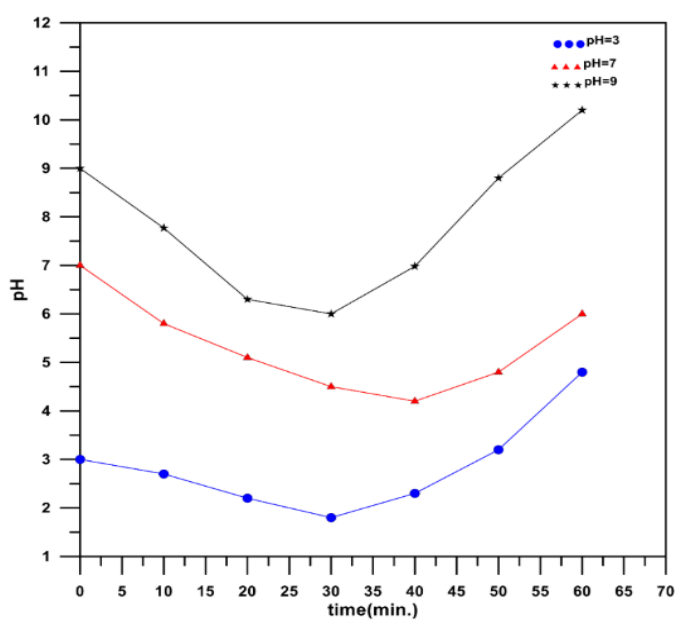

Figure $7 \mathrm{pH}$ profile with time at different initial $\mathrm{pH}$ 


\section{Conclusions}

Anodic oxidation using graphite anodes seems to be more efficient method for treatment of wastewater produced from Al-Diwaniyah petroleum refinery plant as confirmed by the present work. Increase in the current density, $\mathrm{NaCl}$ concentration resulted in an increase of COD and phenol removal efficiencies, while increasing the initial $\mathrm{pH}$ higher than 7 resulted in decreasing of COD and phenol removal efficiencies. Based on the results of this work, current density has a significant effect on the COD and phenol removal than the other variables.

By adjusting initial $\mathrm{pH}$ to a value of 7 , adding $\mathrm{NaCl}$ at concentration of $2 \mathrm{~g} / 1$ and applying current density of $12 \mathrm{~mA} \mathrm{~cm}^{-2}$ for an interval of time equal to $60 \mathrm{~min}$, a complete removal of $\operatorname{COD}(100 \%)$ with phenol removal efficiency of $99.12 \%$ were achieved in which values of current efficiency $(33.5 \%)$ and energy consumption $(59.9 \mathrm{kWh} / \mathrm{kg})$ were observed. The energy consumption in the present work is relatively lower than that reported in previous works in the field of petroleum refinery effluent treatment using other anodes [19, 34, 37].

\section{Acknowledgements}

The authors appreciate the unlimited help and technical assistance provided by the staff of Chemical Engineering Department, College of EngineeringUniversity of Al-Qadisiyah.

\section{REFERENCES}

[1] Y. Yavuz, A.S. Koparal, U.B. Ogutveren, Treatment of petroleum refinery wastewater by electrochemical methods, Desalination, 258 (2010) 201-205.

[2] A. Coelho, A. V. Castro, M. Dezotti, G. L.Sant'Anna, Treatment of petroleum refinery sourwater by advanced oxidation processes. Journal of hazardous materials137 (1)(2006) 178- 184.

[3] A.M.Z. Ramalho, C.A. Martínez-Huitle, D.R. Silva, Application of electrochemical technology for removing petroleum hydrocarbons from produced water using a DSA-type anode at different flow rates, Fuel, 89 (2010) 531-534.

[4] Q.J. Rasheed, K. Pandian, K. Muthukumar , Treatment of petroleum refinery wastewater by ultrasound-dispersed nanoscale zero-valent iron particles. Ultrason Sonochem, 18(2011) 1138-1142. [5] WBG (World Bank Group), Pollution Prevention and Abatement Handbook: Toward Cleaner Production, Washington, D.C., USA, 1999.

[6] Y. Han, X. Quan, S. Chen, H. Zhao, C. Cui, and Y. Zhao, Electrochemically enhanced adsorption of phenol on activated carbon fibers in basic aqueous solution, Journal of Colloid and Interface Science, 299(2)(2006)766-771.

[7] H. Jiang, Y. Fang, Y. Fu, and Q. X. Guo, Studies on the extraction of phenol in wastewater, Journal of Hazardous Materials, 101 (2) (2003)179-190.

[8] L.N. Mota, Development of a photochemistry reactor applicable in the treatment of phenolic wastewater present in the petroleum industry, Master's Thesis, Rio Grande do Norte Federal University, Brazil, 2005,ftp://ftp.ufrn.br/pub/biblioteca/ ext/bdtd/AndreLNM (in Portuguese).

[9] M.H. El-Naas, S. Al-Zuhair, A. Al-Lobaney and S. Makhlouf. Assessment of Electrocoagulation for the Treatment of Petroleum Refinery Wastewater. Journal of environmental management, 91 (2009) 180.

[10] O. Abdelwahab, N. Amin and E.Z. ElAshtoukhy.Electrochemical removal of phenol from oil refinery wastewater, J. Hazard. Mater. , 163 (2009) 711.

[11] A. Coelho, A. V. Castro, M'arcia Dezotti, and G.L. Sant'Anna, Treatment of petroleum refinery sourwater by advanced oxidation processes॥, Journal of Hazardous Materials, B137 (2006)178-184.
[12] M.H. El-Naas, S. Al-Zuhair and M.A. Alhaija, J. Hazard. Mater.Reduction of COD in refinery wastewater through adsorption on date-pit activated carbon.173 (2010) 750

[13] F. Ma, J.-b. Guo, L.-j. Zhao, C.-c. Chang and D. Cui. Application of bioaugmentation to improve the activated sludge system into the contact oxidation system treating petrochemical wastewater.Bioresource technology, 100 (2009) 597.

[14] Y.S. Li, L. Yan, C.B. Xiang and L.J. Hon. Treatment of oily wastewater by organic-inorganic composite tubular ultrafiltration (UF) membranes. Desalination, 196 (2006) 76.

[15] Y. Yavuz and A.S. Koparal, J. Hazard. Mater. Electrochemical oxidation of phenol in a parallel plate reactor using ruthenium mixed metal oxide electrode ,136 (2006) 296.

[16] Y. Yavuz, A.S. Koparal and Ü.B. Öğütveren, Treatment of Petroleum Refinery Wastewater by Electrochemical methods. J. Environ. Eng. 134 (2008) 24.

[17] Y. Zheng, A. Wang, H. Lin, L. Fu and W. Cai. A sensitive electrochemical sensor for direct phoxim detection based on an electrodeposited reduced graphene oxide-gold nanocomposite. RSC Advances, 5 (2015) 15425.

[18] O. Abdelwahab, N.K. Amin, E-S.Z. El-Ashtoukhy, Electrochemical removal of phenol from oil refinery wastewater, Journal of Hazardous Materials, 163 (2009) 711-716.

[19] R.B.A. Souza, L.A.M. Ruotolo, Electrochemical treatment of oil refinery effluent using boron-doped diamond anodes, Journal of Environmental Chemical Engineering 1 (2013) 544-551.

[20] A. Anglada, A. Urtiaga, I. Ortiz, Contributions of electrochemical oxidation to waste-water treatment: fundamentals and review of applications, J. Chem. Technol. Biotechnol. 84 (2009) $1747-1755$.

[21] J. Sun, H. Lu, H. Lin, L. Du, W. Huang, H. Li, Electrochemical oxidation of aqueous phenol at low concentration using Ti/BDD electrode, Sep. Purif. Technol. 88 (2012)116-120.

[22] E. Weiss, K. Groenen-Serrano, A. Savall, A comparison of electrochemical degradation of phenol on boron doped diamond and lead dioxide anodes, J. Appl. Electrochem. 38 (2008) 329-337.

[23] L.S. Andrade, R.C. Rocha-Filho, N. Bocchi, S.R. Biaggio, J. Iniesta, V. Garc1'a-Garcia, V.Montiel, Degradation of phenol using $\mathrm{Co}-$ and $\mathrm{Co}, \mathrm{F}$-doped $\mathrm{PbO} 2$ anodes in electrochemical filter-press cells, J. Hazard. Mater. 153 (2008) 252-260.

[24] C. Borras, C. Berzoy, J. Mostany, J.C. Herrera, B.R. Scharifker, A comparison of the electrooxidation kinetics of p-methoxyphenol and p-nitrophenol on Sb-doped SnO2surfaces: concentration and temperature effects, Appl. Catal. B 72 (2007) 98-104.

[25] D. Rajkumar, J.G. Kim, Oxidation of various reactive dyes with in situ electro generated active chlorine for textile dyeing industry wastewater treatment, J. Hazard. Mater. 136 (2006) 203-212.

[26] A. H. Abbar, R. H. Salman, and A. S. Abbas, Electrochemical Incineration of Oxalic Acid at Manganese Dioxide Rotating Cylinder Anode: Role of Operative Parameters in the Presence of $\mathrm{NaCl}$. Journal of The Electrochemical Society, 163 (13) (2016)E333-E340 [27] S. Palmas, A.M. Polcaro, A. Vacca, M. Mascia, F. Ferrara, Influence of the operating conditions on the electrochemical disinfection process of natural waters at BDD electrodes, J. Appl. Electrochem. , 37 (2007) 1357-1365.

[28] M. Panizza, G. Cerisola, Electrocatalytic materials for the electrochemical oxidation of synthetic dyes, Appl. Catal. , B 75 (2007) 95-101.

[29] I.D. Santos, J.C. Afonso, A.J.B. Dutra, Behavior of a Ti/RuO2 anode in concentrated chloride medium for phenol and their chlorinated intermediates electrooxidation, Sep. Purif. Technol., 76 (2010) 151-157.

[30] J.M. Aquino, M.A. Rodrigo, R.C. Rocha-Filho, C. Sa' ez, P. Can izares, Influence of the supporting electrolyte on the electrolysis of dyes with conductive-diamond anodes, Chem. Eng. J., 184 (2012) 221-227.

[31] Hach Company ,Phenols test , Method 8047, https://www.google.com/url?sa=t\&rct=j\&q=\&esrc=s\&source=web $\& \mathrm{~cd}=1 \& \mathrm{cad}=\mathrm{rja} \&$ uact $=8 \& \mathrm{ved}=2$ ahUKEwj-15rdu $8 \mathrm{DjAhW}-$ QEEAHfGbBL0QFjAAegQIBRAC\&url=https\%3A\%2F\%2Fwww.h ach.com\%2Fasset-get.download- 
en.jsa\%3Fcode\%3D55864\&usg=AOvVaw1_zRXcmsLJbp_0Wlv5B $5 \mathrm{~PB}$

[32] O. Abdelwahab, N. K. Amin, and E. S. Z. El-Ashtoukhy, "Electrochemical removal of phenol from oil refinery wastewater," Journal of Hazardous Materials, 163(2-3) (2009) 711-716.

[33] Y.H. Wang, K.Y. Chan, S.A. Cheng, X.Y. Li, Electrolytic Generation of Ozone on Antimony- and Nickel-Doped Tin Oxide Electrode. J Electrochem Soc., 152(2005) D197-D200.

[34] D. S. Ibrahim, P. S. Devi, N. Balasubramanian, Electrochemical Oxidation Treatment of Petroleum Refinery Effluent, International Journal of Scientific \& Engineering Research, 4(8) August 2013.

[35] M Panizza, P. A. Michaud, G. Cerisola, C. Comninellis, Anodic oxidation of 2-naphthol at boron-doped diamond electrodes. Journal of Electroanalytical Chemistry, 507(1, 2) (2001) 206-214.

[36] Y. H. Wang and J.Y. Kuang, Electrochemical Treatment of Oilfield Produced Wastewater on Ni-Sb-SnO2/Ti Electrodes, J. Adv. Oxid. Technol. , 16(2) (2013).
[37] I. D. Santos. M. Dezotti, A. J.B. Dutra, Electrochemical treatment of effluents from petroleum industry using a $\mathrm{Ti} / \mathrm{RuO} 2$ anode, Chemical Engineering Journal, 226 (2013) 293-299.

[38] P.H. Britto-Costa and L.A.M. Ruotolo, Phenol removal from wastewaters by electrochemicaloxidation using boron doped diamond (BDD) and Ti/Ti0.7Ru0.3O2 DS Aelectrodes, Braz. J. Chem. Eng. , 29 (2012) 763-773

[39] B. A. F1l ,R. Boncukcuoğlu, A. E. Yilmaz, S. Bayar, ElectroOxidation of Pistachio Processing Industry Wastewater Using Graphite Anode. Clean - Soil, Air, Water, (2014) 1232-1238.

[40] O. Scialdone, S. Randazzo, A. Galia, G. Silvestri, Electrochemical oxidation of organics in water: Role of operative parameters in the absence and in the presence of $\mathrm{NaCl}$, Water Res. , 43 (2009) 2260-2272. 